\title{
Bison foraging responds to fire frequency in nutritionally heterogeneous grassland
}

\author{
Edward J. Raynor, ${ }^{1}$ Anthony Joern, And John M. Briggs \\ Division of Biology, 116 Ackert Hall, Kansas State University, Manhattan, Kansas 66506 USA
}

\begin{abstract}
Foraging decisions by native grazers in fire-dependent landscapes modulate the fire-grazing interaction. Uncovering the behavioral mechanisms associated with the attraction of grazers to recently burned areas requires understanding at multiple spatial scales in the ecological foraging hierarchy. This study focused on feeding in the area between steps in a foraging bout, the feeding station, as forage chemistry and vegetation architecture play central roles in these fine-scale, feeding-station decisions. The forage maturation hypothesis (FMH) uses the temporal dynamics of forage quality and quantity in grasslands to explain the distribution of large herbivores, but does not address herbivore responses to inter-patch variation caused by fire-induced nutrient increases of forage quality. Using an experimental setting with contrasting fire treatments we describe the effects of variable burn history on foraging kinetics by bison at Konza Prairie Biological Station (KPBS). We assessed the potential to link the FMH in a complementary fashion to the transient maxima hypothesis (TMH) to explain temporal variation in bison responses to grassland forage quality and quantity in response to burning at different temporal frequencies. Forage attributes met predictions of the TMH that allowed us to investigate how forage maturation affects feeding station foraging behavior across watersheds with varying burn frequency. At sites burned in the spring after several years without burning, both bite mass and intake rate increased with increasing biomass at a greater rate during the growing season than during the transitional midsummer seasonal period. In these infrequently burned watersheds, early growing season bite mass $(0.6 \pm 0.05 \mathrm{~g}$; mean $\pm \mathrm{SE})$, bite rate $(38 \pm 1.5 \mathrm{bites} / \mathrm{min})$, and intake rate $(21 \pm 2.3$ $\mathrm{g} / \mathrm{min}$ ) was reduced by $\sim 15 \%, 13 \%$, and $29 \%$ during the midsummer transitional period. A behavioral response in foraging kinetics at the feeding station occurred where a nonequilibrial pulse of high-quality resource was made available and then retained by repeated grazing over the growing season. Our results provide the first experimental evidence for demonstrating the fine-scale behavioral response of a large grazer to fire-induced changes in forage attributes, while linking two prominent hypotheses proposed to explain spatial variation in forage quality and quantity at local and landscape scales.
\end{abstract}

Key words: fire ecology; forage maturation hypothesis; grassland; grazing; nutritional ecology; tallgrass prairie; transient maxima hypothesis.

\section{INTRODUCTION}

In grasslands, spatial and temporal variation in forage quality and quantity results from multiple interacting abiotic factors such as precipitation, topography, and soil nutrients, which in turn affect the foraging behavior of grazing ungulate herbivores (Owen-Smith 2002, Prins and van Langevelde 2008). Equally important, such heterogeneity in forage quantity and quality in a landscape also reflects recursive fire-grazer interactions (Milchunas et al. 1988, Fuhlendorf and Engle 2001, Archibald et al. 2005, Anderson et al. 2007). Fire in grasslands creates an "ecological magnet" for many grazer species (Archibald et al. 2005), resulting in heavy selection and sustained use of regrowth in post-burned areas (Coppedge and Shaw 1998, Sensenig et al. 2010,

Manuscript received 21 October 2014; accepted 3 December 2014. Corresponding Editor: R. W. Ruess.

${ }^{1}$ E-mail: ejraynor@ksu.edu
Eby et al. 2014). In turn, recent grazing reduces fuel and the likelihood a patch will burn in the near future. While the spatial distributions and movement patterns of large herbivores in response to recent fires are increasingly understood at coarse-scale landscape levels (Vinton et al. 1993, Schuler et al. 2006, Allred et al. 2011a, b, Augustine and Derner 2014), much remains to be learned about how fire-grazing interactions affect foraging at fine scales, i.e., the feeding station level. A feeding station is defined as the forage available to an herbivore without moving its front feet during a foraging bout (Bailey et al. 1996). The feeding station is the spatial unit of finest ecological resolution in the ecological hierarchy where foraging decisions are made that can affect coarser-scale distributional decisions (Morris 1987, Senft et al. 1987).

Fryxell (1991) modeled the forage maturation hypothesis (FMH) (McNaughton 1986, Hobbs and Swift 1988) as a trade-off between forage quality and quantity 
to evaluate grazer behavior at multiple scales, providing a framework to understand patch use and the spatial and temporal distributions of grazing herbivores (Wilmhurst et al. 1999, Hebblewhite et al. 2008, Dancose et al. 2011, Bischof et al. 2012). In this model, optimal intake rates by foragers occur at low to intermediate levels of forage biomass. FMH posits that aggregations of large herbivores reflect optimal combinations of forage quality and quantity to maximize intake rate (Fryxell 1991). In turn, collective consumption pressure at intermediate to high grazer densities may maintain vegetation in a state of low to intermediate forage quantity but high quality through regrowth of young forage tissue (McNaughton 1979, Fryxell 1991); i.e., seasonal maturation to high biomass is repressed by repeated foraging pressure.

Fire is a major ecosystem driver in many grasslands, where it leads to spatially heterogeneous distributions of forage quality, appearing as a shifting mosaic within and among years depending on the time since a patch last burned. Fire significantly increases leaf nutrient concentrations in post-fire growth (Blair 1997, van de Vijver et al. 1999) while removing older, non-palatable tissues (Pfeiffer and Hartnett 1995). Complementary to direct grazer-vegetation interactions and the $\mathrm{FMH}$, the Transient Maxima Hypothesis (TMH) (Seastedt and Knapp 1993, Blair 1997) describes the development of a shifting mosaic of vegetation quantity and quality in response to fire-mediated release from resource limitations in tallgrass prairie with great potential to influence grazer-fire interactions. In tallgrass prairie, primary productivity is often co-limited by light, energy, and soil nutrients, with the relative importance of individual resources dependent on time since last fire (Blair 1997). Annually burned grassland receives sufficient light, and temperatures are non-limiting, but soil nitrogen becomes limiting. For unburned grassland when litter accumulates, light/temperature is limiting, and available soil-N increases with time, as it is not fully used by plants.

A post-fire "pulsed" increase in ANPP occurs in vegetation that is released from an extended period of fire suppression. An abrupt release of light limitation coupled to the availability of increased accumulation of available soil nitrogen leads to a short-lived, nonequilibrium pulse in ANPP. This nonequilibrium period is referred to as a "transient maxima," when availability of both potentially limiting factors is sufficient to support increased ANPP (Seastedt and Knapp 1993). In tests of the TMH in tallgrass prairie, Blair (1997) found increased ANPP and higher concentrations of shoot tissue nitrogen $(\mathrm{N})$ in years with burning when vegetation was exposed to intermediate fire frequencies (e.g., every several years) compared to annual burning or long periods of fire suppression (Fig. 1A; Blair 1997). Enhanced ANPP and plant tissue-N content following an infrequent fire derive from the ability of vegetation to exploit higher soil inorganic and mineralizable-N accumulated in the absence of fire, under new high-light
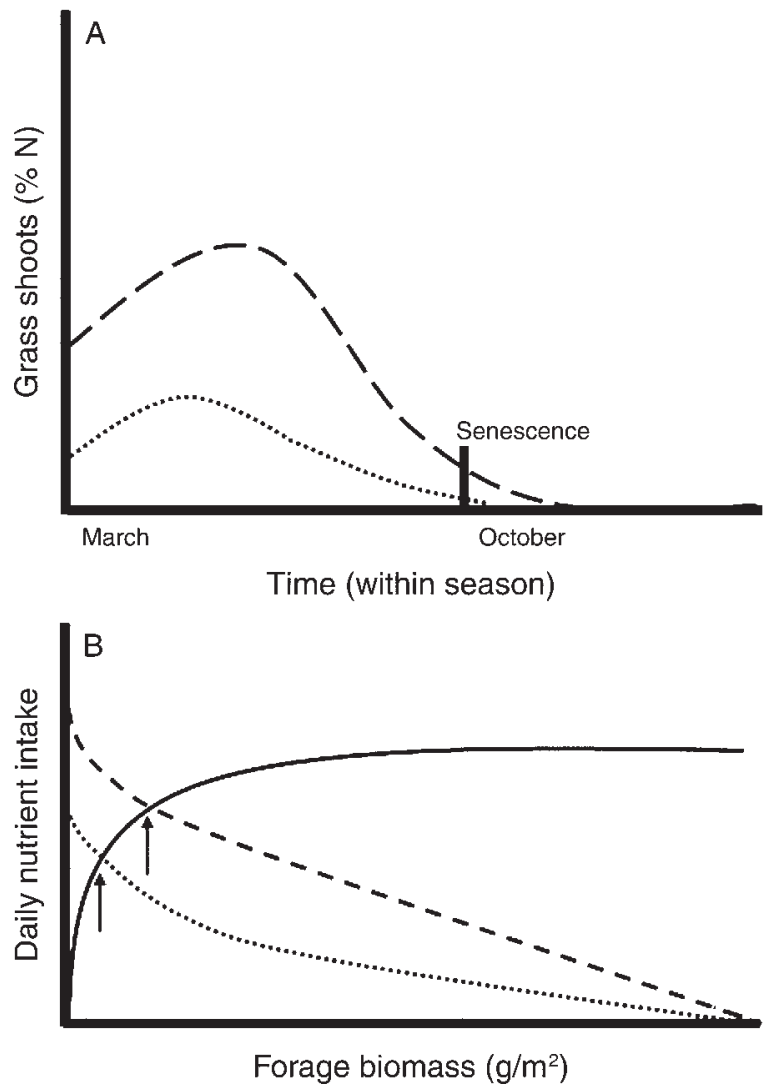

FIG. 1. (A) Graphical illustration of the transient maxima hypothesis, which predicts transient "pulses" of plant $\mathrm{N}$ availability (dashed line) that are greater than the average $\mathrm{N}$ availability in tallgrass prairie that is annually burned (finedotted line) sites as a result of increased light availability and gradually declining $\mathrm{N}$ availability as plants senesce. Note that the figure illustrates patterns of change over a post-spring burn period in a year. (B) Schematic showing general mechanisms of the forage maturation hypothesis (FMH) complemented by the transient maxima hypothesis (TMH). Foraging constraints of daily cropping (solid line) and digestion in frequently burned (fine-dotted line) and infrequently burned (dashed line) grassland that result in a foraging optima (arrows) at low-tointermediate biomass. (Modified from Fryxell 1991).

conditions. Moreover, net N-mineralization rates and foliar- $\mathrm{N}$ content both decline with successive annual spring burning, ultimately reducing nutritional quality available to grazers; unburned sites provide less palatable forage because of the significant proportion of mature, low-quality leaf tissue in standing vegetation (Vinton et al. 1993, Pfeiffer and Hartnett 1995, Knapp et al. 1999). Consequently, a shifting mosaic of areas of varying fire frequency can modulate the spatial and temporal distribution of large herbivores through combined effects on forage quality and quantity (Fuhlendorf and Engle 2004, Fuhlendorf et al. 2009) similar to the FMH. Differences in nutrient value and palatability of forage available in areas burned frequently, infrequently, and not burned should alter foraging 
behavior at the feeding station level where diet selection occurs (Senft et al. 1987).

The overall significance of the fire-grazing interaction can be determined by examining how fire influences grazing behavior, the key to understanding the link between fire and grazing (Fuhlendorf and Engle 2004, Allred et al. 2011a). Although it is well known that large grazers are attracted to recently burned grassland, the mechanisms that drive forage nutrient availability and resulting fine-scale foraging behavior after a fire remain unexplored. For example, the initial post-fire surge in forage nutrient availability in infrequently burned grassland (TMH) may interact with subsequent concentrated grazing pressure $(\mathrm{FMH})$ to maintain grassland in a state of elevated forage quality and quantity, where large herbivores realize short-term benefits in nutrient acquisition (Fig. 1B). The shifting mosaic from both fireinduced and concomitant grazing-enhanced forage quality is well known (Schuler et al. 2006, Allred et al. 2011 b, Eby et al. 2014). Here, we hypothesize that mechanisms underlying FMH and TMH interact as two complementary diet optimization drivers that guide bison distributions during short-term periods. Because protein (i.e., $\mathrm{N}$ content) is often a limiting factor for ungulate performance (Van Soest 1996), foraging responses to variable fire frequency and associated plant responses will provide insight into how frequent and infrequent fires impact bison behavior.

To date, few if any studies have directly quantified and compared fine-scale foraging behavior by ungulates at the feeding-station scale in grasslands managed under variable burning regimes. Most studies are conducted in unburned grasslands (but see Shrader et al. 2006), and studies evaluating ungulate preference for burned areas have not investigated detailed foraging kinetics (Vinton et al. 1993, Sensenig et al. 2010, Allred et al. 2011a,b). Moreover, no investigations have linked the TMH as a mechanism to complement the FMH in explaining largeherbivore foraging behavior. Coarse-scale distributional patterns of grazers indicate that an elevated response of forage quality to fire after a period of reduced light availability initially attracts ungulates to the recently burned area (Eby et al. 2014). Furthermore, total compensation of grass and forbs occurs in recently burned, bison-grazed watersheds at Konza Prairie (Knapp et al. 2012). We hypothesize that repeated grazing maintains periodically burned areas in a state of low-to-intermediate biomass until forage senescence occurs. With senescence, bison no longer select recently burned areas, and their spatial distributions become random and directed towards forage-laden, unburned watersheds during the dormant season. This was observed at Konza Prairie (Vinton et al. 1993). Loss of high-quality forage can be expected to change ungulate foraging behavior and to lower within-season site fidelity (Wittmer et al. 2006).

An inverse relationship between leaf development stage and protein content and forage digestibility (Waite
1963, Miller et al. 1965), predicts a positive feedback between grazing activity and forage palatability (Archibald et al. 2005, Verweij et al. 2006, Kerby et al. 2007), a tenet of FMH. Forage quantity influences grazer foraging behavior at the feeding station scale (Ruyle et al. 1987, Drescher et al. 2006), outcomes that are sure to be influenced by fire-induced alterations in forage quality that are in need of study.

Here, we examine the foraging behavior of the plains bison (Bison bison) in tallgrass prairie at Konza Prairie Biological Station (KPBS) as individuals freely selected forage among multiple watersheds that differ in fire and grazing history. We first evaluated how vegetation quantity and nutritional quality varied throughout the growing and dormant seasons across watersheds burned at different frequencies, and then quantified how vegetation attributes under different burn histories influenced bite mass, bite rate, and instantaneous intake rate of focal individuals. We predicted: (a) intake rate would increase with biomass on feeding stations of high quality, and bite rate should eventually decline at high biomass; (b) intake rate would increase at a greater rate in infrequently burned watersheds in years of burning, where protein availability is greatest, (c) a behavioral response to a fire-induced transient maxima in infrequently burned grassland would maintain infrequently burned grassland in a state of low-to-intermediate forage quantity; (d) a behavioral response in foraging kinetics to fire-induced nutrient enhancement of frequently burned watersheds would be minimal; and (e) foraging kinetics in frequently burned watersheds would be similar to that observed in unburned watersheds because ANPP has been reported to be similar between the two fire regimes in bison-grazed watersheds at KPBS (Knapp et al. 2012). We interpret and discuss our results relative to feeding stations in a fire-dependent landscape using the framework linking TMH and $\mathrm{FMH}$, as previously described.

\section{Methods \\ Study area}

Konza Prairie Biological Station (KPBS) is 3487 ha of native, $\mathrm{C}_{4}$-dominated grassland in the Flint Hills of northeastern Kansas $\left(39^{\circ} 05^{\prime} \mathrm{N}\right.$ and $\left.96^{\circ} 35^{\prime} \mathrm{W}\right)$, located $\sim 13 \mathrm{~km}$ south of Manhattan, Kansas, USA. The site is representative of Flint Hills tallgrass prairie with a variable continental climate with warm, wet springs, hot summers, and dry, cold winters. The 32-year mean annual precipitation (1982 to 2013) is $832.9 \pm 61.1 \mathrm{~mm}$, with $\sim 75 \%$ falling during April to September. KPBS experienced below average precipitation in 2012 (568.9 $\mathrm{mm}$, a deviation of $-46 \%$ from the annual average precipitation), while 2011 ( $814 \mathrm{~mm},-2 \%$ from the annual average annual precipitation) and 2013 (783.4 $\mathrm{mm},-6 \%$ from the annual average precipitation) were near average precipitation. Vegetation is mostly native tallgrass prairie $(>90 \%)$ dominated by $\mathrm{C}_{4}$ perennial grasses (Andropogon gerardii, Sorghastrum nutans, Pan- 
icum virgatum, and Schizachyrium scoparium), where interstitial forbs constitute $>75 \%$ of species richness ( $\sim 575$ species) (Towne 2002). Bison have access to a contiguous 1012-ha fenced enclosure comprising 10 hydrologically delineated watersheds with different fire treatments. Two replicate watersheds each have been burned in the spring since 1988 at one of three fire frequencies (1,2, and 20 years), while four watersheds have been burned once every four years. Hereafter, we refer to watersheds with fire frequencies of 1-2 years and that did burn in the spring (late March-early April) prior to focal animal observations (late April to December) as frequently burned watersheds $(n=3$ in both years). Watersheds with fire frequencies of 4 or 20 years and that burned in the spring prior to focal animal observation are referred to as "infrequently burned" watersheds ( $n=2$ in 2012, $n=1$ in 2013). Watersheds that were not burned ( $n=5$ in 2012, $n=6$ in 2013) in the spring prior to our observations are referred to as "notburned" sites in this study, regardless of the historical burn frequency. Bison stocking rate is currently maintained at $\sim 260$ adults (plus $\sim 100$ spring-born calves) annually or $\sim 0.3 \pm 0.01$ animals $/$ ha, resulting in a target density that removes $\sim 25$ of the ANPP.

\section{Focal sampling}

To quantify fine-scale behavior, foraging bouts $(n=$ 208) of individual adult bison (excluding yearlings and calves) were recorded $(1.4 \pm 0.05$ observations per individual) with a digital video camera using focal animal protocol (Altmann 1974) for at least 5 minutes (range: 5-10 min). Observations were done from May to December in 2012 and 2013 in replicated frequently, infrequently burned, and not-burned watersheds. Video footage of focal animals was scored with behavioral analysis software (Observer XT v11.0; Biopac Systems, Goleta, California, USA) for bite number, displacement of the front feet, head raising and lowering, and when an animal lays down. Video was recorded from the cab of a truck parked on-site at a distance of $10-100 \mathrm{~m}$ for at least 10 minutes prior to recording to allow bison to acclimate to its presence and thus minimize disturbance to feeding from the presence of the observer.

\section{Vegetation surveys at feeding stations}

Following each observation of bison feeding, forage attributes were measured using three ungrazed quadrats at arbitrary locations parallel to the observed foraging area monitored during the 5-min foraging bout. Quadrats consisted of $1-\mathrm{m}^{2}$ sampling frames split into five $0.2-\mathrm{m}^{2}$ subplots placed within a $10 \mathrm{~m}$ radius circle centered on the feeding location (Schaefer and Messier 1995). In every subplot, plant cover and percentage of green material was estimated visually using $10 \%$ classes in four vegetation groups: grasses and sedges, forbs (all herbaceous dicots), litter (previous year's dead grass), and bare ground. Mean grass height was calculated by measuring three representative plants to the nearest centimeter at 20 points along a $30-\mathrm{m}$ transect running parallel to the grazed path. Total dry plant biomass $(B$, in grams per square meter) was estimated by clipping standing biomass to $1 \mathrm{~cm}$ height from a $0.1-\mathrm{m}^{2}$ sampling frame placed parallel to the foraging path. Three $0.1-\mathrm{m}^{2}$ swaths were clipped and adjusted to $1 \mathrm{~m}^{2}$. Total biomass was then multiplied by proportions of graminoids, forbs, and litter determined from visual percentage cover estimates to estimate biomass of the three vegetation elements. To estimate forage quality at feeding stations, three swaths of vegetation within $2 \mathrm{~m}$ parallel to the foraging path were clipped to $1 \mathrm{~cm}$ height from a $0.1-\mathrm{m}^{2}$ sampling frame ( $<24$ hours since grazed).

Samples were dried for 48 hours at $60^{\circ} \mathrm{C}$ to a constant mass, and sorted into graminoids, forbs, and litter. Because graminoids comprise $98 \%$ of the year-round diet of bison in tallgrass prairie (Coppedge et al. 1998), graminoids were separated from clipped vegetation samples and analyzed for nutrient content. For each foraging observation sample, two of the three clipped graminoid samples were randomly selected for nutrient analysis. Graminoid nutritional properties, including lignin, NDF (neutral detergent fiber), N (crude protein), $\mathrm{P}$, and in vitro digestibility after 30 hours were determined using NIRS (near infrared spectroscopy) analysis. Crude protein was estimated as $\%-\mathrm{N}$ in plant tissue $\times 6.25$, while NDF is inversely related to forage quality as it indicates the relative amount of cellulose and lignin in plant tissue, both of which reduce forage digestibility. A total of 470 samples of feeding station biomass, 2-3 samples per foraging observation, were dried, ground to a 1-mm particle size, and analyzed by Dairyland Laboratories (Arcadia, Wisconsin, USA) on a Foss model 5000 NIR instrument (Foss, Hillerød, Denmark). Appendix A describes methodology for permanent vegetation sampling stations established to determine temporal variation in vegetation in each watershed in the bison enclosure.

\section{Estimation of bite size}

Within a $1 \mathrm{~m}$ radius circle of each feeding station for each animal observation period, we located 3-4 small square quadrats $(9.5 \times 9.5 \mathrm{~cm})$ per sampled feeding station, corresponding to approximate width and snout length of a bison's mouth (Janis and Ehrhardt 1988), and clipped grass to the average grazing depth parallel to the observed feeding station. We estimated bite mass by first measuring with a ruler the grazing depth of the 10 nearest grazed plants from the center of the foraging path, and calculated the mean grazing depth (St-Louis and Côté 2012). Bite samples were oven dried for 48 hours at $60^{\circ} \mathrm{C}$, and weighed using a $0.001-\mathrm{g}$ precision balance. Bite quality was evaluated as a function of bite sample digestibility and NDF content (Drescher et al. 2006). The 10 bite subsamples for each foraging observation were combined for nutrient analysis, so that bite quality represents the nutrient quality of 10 combined subsamples. 
Ingestion time

Bite rate was measured by scoring foraging bout video using Noldus Observer XT V.11 software (Noldus Information Technology, Wageningen, The Netherlands) programmed to record the number of bites taken per feeding step and the number of bites per second. Each observation spanned at least $5 \mathrm{~min}$ (range, 5-10 min) from an average distance of $20 \mathrm{~m}$ in a truck. A feeding step was defined as a single step with one of the front legs where the bison took at least one bite. Observations of bite rate did not include non-feeding steps. Bite rate was calculated by dividing the total number of bites by the time taken in feeding steps.

Instantaneous forage intake rate was calculated as the product of bite rate and bite size. Because intake rate of dry matter at feeding stations by ungulates is limited by ingestion time (Spalinger and Hobbs 1992), we used functional responses estimated during foraging bouts to determine the ingestion time of forage. We determined dry matter forage intake rate ( $I$, grams per minute) by multiplying the bite rate (BR, bites per minute) derived from analysis of foraging videos by bite mass (BM, grams per bite). Forage intake rate was then related to forage biomass $(B)$ using the Michaelis-Menten form of the type II functional response $M B /(\beta+B)$, where $M$ is the maximum feeding rate (grams per minute) and $\beta$ is the half-saturation constant (in grams per square meter). Appendix B summarizes the methodology for estimation of feeding station nutrient intake rate and recent grazing activity.

\section{Data analysis}

A mixed linear model was used to determine variation in total grass biomass and crude protein content of grass shoots for burn treatments, seasonal periods, and years. Fire treatment, seasonal period, and year were main effects, with month within seasonal period included as the random effect. Observations were delineated to three seasonal periods: growing (15 April-30 June), mid-to-late summer transition (1 July7 October), and dormant (8 October-31 December). Sattherwaite's approximation was used to calculate effective degrees of freedom of a linear combination of independent sample variances.

A general linear model was used to analyze the variation in mean bite mass, bite rate, and intake rate with burn treatment, seasonal period, and station grass biomass. Functional response relationships for bite mass, bite rate, and short-term intake rate were derived using the ungrazed forage characteristics adjacent to the foraging path. Prior to performing ANCOVA to compare slopes and intercepts of the seasonal trends in foraging behavior relative to grass biomass, we contrasted the slopes of the categorical variables of interest relative to forage biomass to test interactions among slopes using SAS system 9.2 (SAS Institute 2010).

\section{RESUlTS}

\section{Temporal trends in grass availability}

Mean standing stock of live and dead grass biomass (grams per square meter) in watersheds grazed by bison averaged across topographic positions was greater in notburned watersheds in comparison to frequently and infrequently burned watersheds burned the previous spring (Fig. 2A). However, grass biomass after the spring burn in 2013 for infrequently burned, grazed watersheds reached levels similar to frequently and not-burned watersheds by the end of the growing season, unlike the consistently low levels of grass biomass for infrequently burned sites in 2012. Analyses of total grass biomass revealed significant main effects of seasonal period $\left(F_{2,7.5}=7.5, P=0.02\right)$ and burn treatment $\left(F_{2,22.7}=8.11, P=0.002\right)$ in addition to a significant year-by-season interaction $\left(F_{2,25}=4.3, P=0.02\right.$; Appendix A: Table A2). The transitional period had greater total grass biomass than the dormant period except in 2012; the transitional period and dormant period had similar levels of grass biomass. Frequently burned and infrequently burned watersheds had significantly less total grass biomass than not-burned watersheds during the study (Appendix A: Fig. A2), which is in accord with the prediction that initial attraction to high-quality forage instigated repeated grazing (Appendix B: Fig. B4). In 2012, grass biomass sampled during the peak of production in an annually burned, ungrazed site (watershed 1D), was $19 \%$ $\left(320.3 \mathrm{~g} / \mathrm{m}^{2}\right)$ below the annual mean of $399.7 \mathrm{~g} / \mathrm{m}^{2}$ estimated from 1989 to 2013 (mean grass biomass averaged over topographical positions, Konza-LTER dataset PAB01). In 2011 this watershed had above average ANPP with $540.6 \mathrm{~g} / \mathrm{m}^{2}(+37 \%)$. In 2013, grass biomass was $38 \%$ above the recorded average with $551.2 \mathrm{~g} / \mathrm{m}^{2}$ ).

Crude protein content of live forage at feeding stations declined as the season progressed in 2012 (curvilinear regression, $F_{1,100}=26.2, R^{2}=0.35, P<0.0001$ ) and 2013 (curvilinear regression, $F_{1,93}=229.3, R^{2}=0.8, P<$ 0.0001 ), although a substantial increase in protein content was evident in late summer 2012 (Fig. 2C, D). Lignin content increased with increasing day of the year in 2012 (curvilinear regression, $F_{1,100}=21.5, R^{2}=0.30, P<$ 0.0001 ) and 2013 (curvilinear regression, $F_{1,93}=42.2, R^{2}$ $=0.48, P<0.0001$; Fig. 2D). Crude protein content of forage peaked during the early growing season of both years, and protein content of forage from infrequently burned watersheds was generally higher throughout the study (Fig. 2E). Analyses of variation in crude protein content of grass shoots by burn treatment revealed a significant difference $\left(F_{2,21.1}=3.43, P=0.05\right)$ in addition to a marginally significant year-by-seasonal-period interaction $\left(F_{2,12.1}=3.67, P=0.06\right.$; Appendix A: Table A1, Fig. A3). Infrequently burned watersheds had higher crude protein content of grass shoots than not-burned watersheds throughout the study (Bonferroni's least squared differences [lsd], $P=0.01$ ), while frequently burned watersheds had marginally lower crude protein content of grass shoots than infrequently burned 

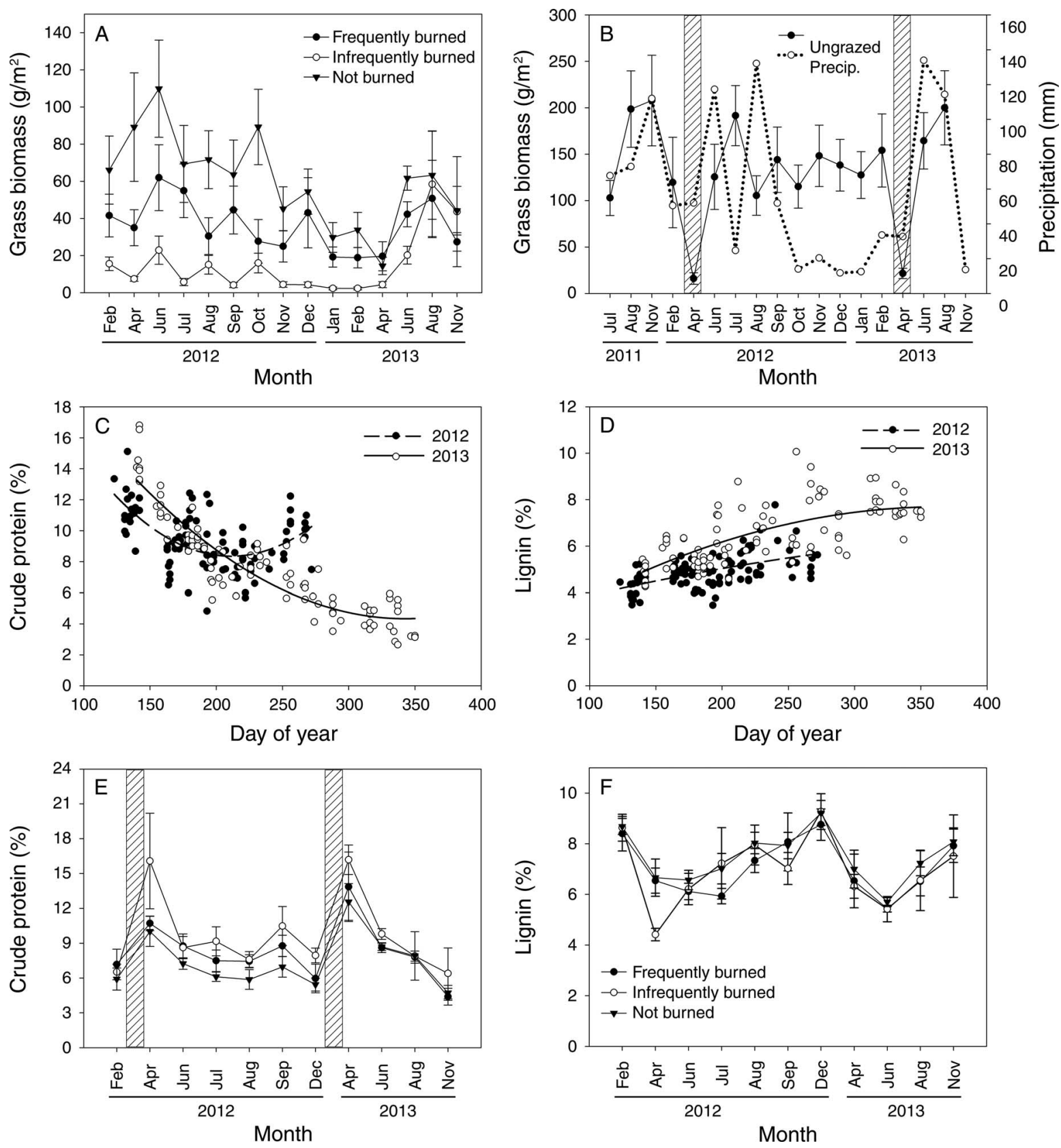

FIg. 2. Seasonal variation in forage properties at Konza Prairie, Manhattan, Kansas, USA. (A) Variation ( \pm SE) in the availability of standing grass biomass recorded along a 6-m transect and averaged for upland and lowland areas in the three burn treatments used by bison. (B) Variation in grass biomass in frequently burned, ungrazed grasslands recorded along a 6-m transect and averaged for upland and lowland topographical areas, 2011-2013. Data are shown with the monthly rainfall pattern; shaded bars indicate when burning occurred. (C) Percentage of crude protein in grass leaf tissue at feeding stations. "Day 1 " is 1 January. (D) Percentage of lignin in grass leaf tissue at feeding stations. (E) Seasonal variation in the crude protein content of grass in the three grassland types available to bison recorded along a 6-m transect and averaged for upland and lowland topographical areas. (F) Seasonal variation in the lignin content of grass in the three grassland types.

watersheds (1sd, $P=0.1$; Appendix A: Fig. A3). The yearby-seasonal period interaction revealed that crude protein content of grass shoots was lower in the 2012 dormant season than in the 2013 dormant season (1sd, $P=0.009$ ).

\section{Functional responses to feeding station biomass}

Bite mass increased linearly with increasing grass biomass across all treatments $\left(F_{2,206}=32.39, P<\right.$ $\left.0.0001, R^{2}=0.14\right)$. The mean bite mass relative to grass 

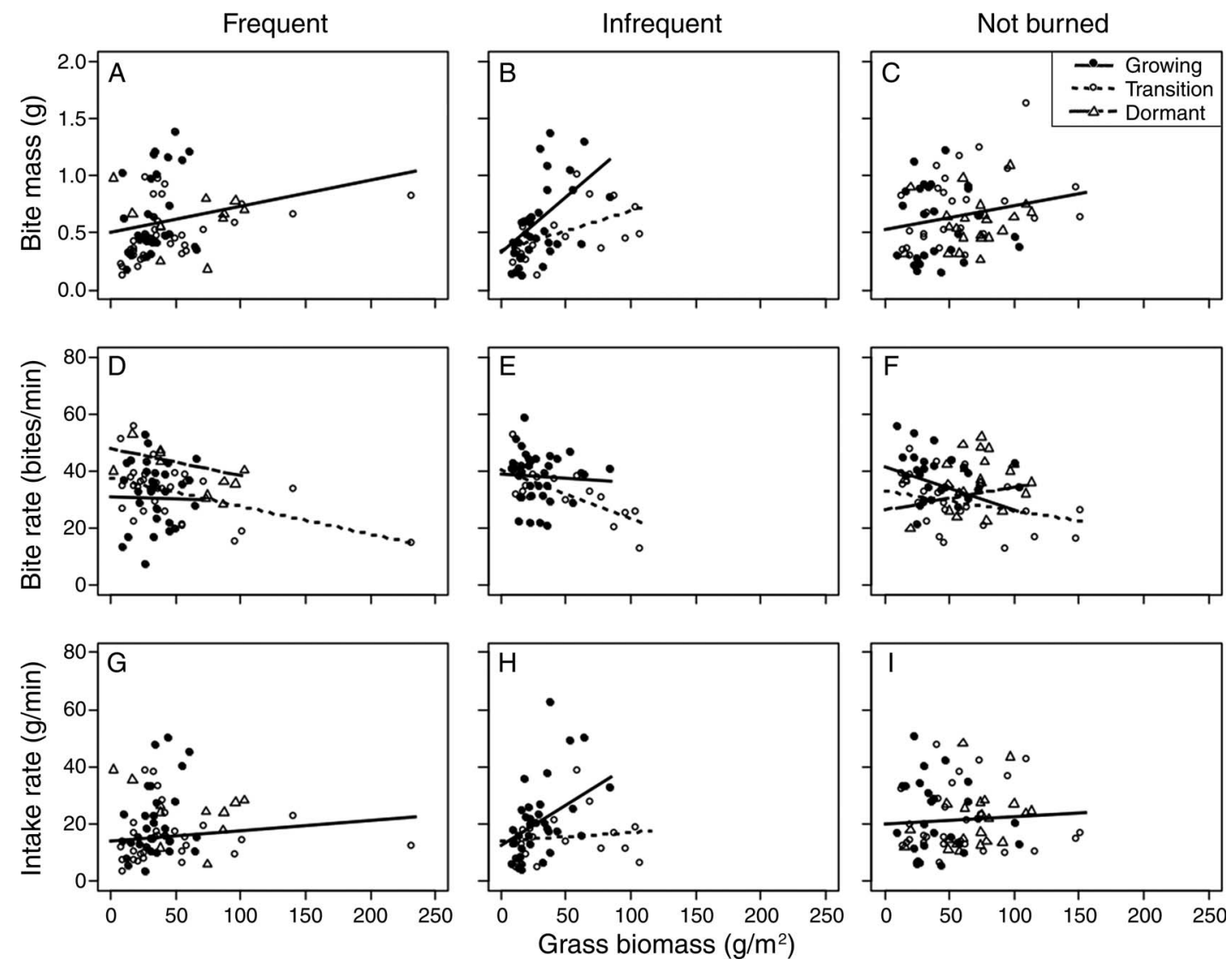

FIG. 3. Functional relationship of bite mass in relation to grass biomass at feeding stations. (A) Frequently burned, (B) infrequently burned, and (C) not-burned grasslands in the different seasons. Similar bite mass was obtained in (C) not-burned grasslands throughout the three seasonal periods, so a single line was fitted to these data. Functional relationship of bite rate in relation to grass biomass at feeding stations of (D) frequently burned, (E) infrequently burned, and (F) not-burned grasslands in the different seasons. Functional relationship of intake rate in relation to grass biomass at feeding stations of $(G)$ frequently burned, (H) infrequently burned, (I) not-burned grasslands in the different seasons. Similar intake rates were obtained in (G) frequently burned and (I) not-burned grasslands throughout the three seasonal periods, so a single line was fitted to these data.

biomass level did not differ significantly among burn treatments $\left(F_{4,198}=1.32, P=0.27\right)$ or among seasons in watersheds that did not burn in the spring prior to observation (slope, $F_{2,76}=1.94, P=0.15$; intercept, $F_{1,76}$ $=5.09, P=0.03$, Fig. 3C). In infrequently burned watersheds, there was a marginally significant interaction between season and grass biomass in the bite mass ANCOVA $\left(F_{1,50}=3.37, P=0.07\right.$; intercept, $F_{1,50}=0.1$, $P=0.75$, Fig. 3B). Thus, we tested whether the slope of the relationship of bite mass with grass biomass differed between seasons. Bite mass differed significantly between growing and transitional seasons independent of differences in grass biomass with growing season bite mass increasing with grass biomass at a greater rate than the transitional season in infrequently burned watersheds. Only five observations in infrequently burned watersheds for the dormant season were available and were not included in analyses. In frequently burned watersheds, the relationship of bite mass to grass biomass did not differ signficantly among seasons (slope, $F_{2,76}=1.12, P=0.33$; intercept, $F_{1,76}=1.25, P$
$=0.29$, Fig. 3A). The upper envelope to the scatter of points suggests that maximum bite mass for each watershed type could be obtained from a feeding station biomass of $40 \mathrm{~g} / \mathrm{m}^{2}$. Overall, the mean bite mass was similar among watersheds types: frequently burned $(0.58$ $\pm 0.1 \mathrm{~g}$; mean $\pm \mathrm{SE})$, infrequently burned $(0.53 \pm 0.1 \mathrm{~g})$, and not-burned $(0.64 \pm 0.1 \mathrm{~g}$; Fig. 4A).

Bite rate declined significantly with increasing grass biomass at the feeding station, averaged across all three burn treatments $\left(F_{2,206}=19.11, P<0.0001, R^{2}=0.08\right)$. Bite rate did not differ significantly among burn treatments $\left(F_{4,198}=0.30, P=0.88\right)$. A seasonal difference in bite rate was measured at feeding stations with similar grass biomass within treatment combinations as seen for frequently burned watersheds (Fig. 3D). Bite rate was greater in the dormant season than the growing season, but not different from the transitional season (slope, $F_{1,67}=0.83, P=0.44$; intercept, $F_{2,67}=$ 2.64, $P=0.08$ ). Because we found a marginally significant interaction between season and grass biomass for bite rate (ANCOVA, $F_{1,53}=2.95, P=0.09$; intercept, 
$F_{1,50}=0.74, P=0.39$, Fig. 3E) in infrequently burned watersheds, we tested whether the slope of bite rate with increasing grass biomass differed between seasons. Bite rate differed significantly between growing and transitional seasons independent of grass biomass differences with transitional season bite rate decreasing at a greater rate than the growing period in infrequently burned sites. This meets our prediction of an inverse relationship between bite mass and bite rate at high-quality feeding stations as biomass increases. In watersheds not burned the spring prior to observation, bite rate was similar among seasons, although the slopes were marginally different with the dormant season having a positive slope while the growing and transitional season bite rate decreased with increasing biomass (slope, $F_{2,71}$ $=1.44, P=0.08$; intercept, $F_{1,71}=1.44, P=0.24$, Fig. $3 \mathrm{~F})$. Maximum bite rates $\sim 55$ bites $/ \mathrm{min}$ were observed in each watershed type on grass biomass up to $40 \mathrm{~g} / \mathrm{m}^{2}$. Mean bite rate in frequently burned $(34 \pm 2.3$ bites/ $\mathrm{min})$, infrequently burned ( $37 \pm 2.4 \mathrm{bites} / \mathrm{min})$, and notburned grassland ( $35 \pm 2.1 \mathrm{bites} / \mathrm{min}$ ) were similar (Fig. $4 B)$.

Intake rate increased linearly with biomass availability at the feeding station across all three burn treatments $\left(F_{2,206}=8.15, R^{2}=0.04, P=0.005\right)$. A maximum limit to the intake rate was reached at feeding stations of $\sim 50$ $\mathrm{g} / \mathrm{m}^{2}(40 \mathrm{~g} / \mathrm{min}$ in frequently burned watersheds; $35 \mathrm{~g} /$ min in infrequently burned; and $50 \mathrm{~g} / \mathrm{min}$ in watersheds not burned in the spring prior to observation). Intake rate relative to total grass biomass at feeding stations did not differ significantly among watershed types $\left(F_{4,206}=\right.$ 1.04, $P=0.36$ ) or among seasons for frequently burned (slope, $F_{1,67}=2.05, P=0.14$; intercept, $F_{2,67}=2.37, P=$ 0.10 ) and not-burned watersheds (slope, $F_{2,71}=0.73, P=$ 0.49 ; intercept, $F_{1,71}=0.63, P=0.54$, Fig. 3G, I). This indicates a minimal response in forage kinetics at feeding stations in frequently burned watersheds and in notburned watersheds, which exhibit similar patterns of productivity (Knapp et al. 2012). In infrequently burned watersheds, a significant interaction between season and grass biomass influenced intake rate (ANCOVA, $F_{1,50}=$ 6.83, $P=0.01$; intercept, $F_{1,50}=0.69, P=0.41$, Fig. $3 \mathrm{H}$ ). Thus, we tested whether the slope of the relationship between intake rate and grass biomass differed between seasons. At infrequently burned sites, intake rate differed significantly between growing and transitional seasons independent of grass biomass, with intake rate during the growing season increasing at a greater rate relative to biomass than during the transitional season. This result met our prediction that a behavioral response in foraging kinetics would occur where a pulse of available nutrients was utilized following infrequent fire. Seasonal intake rate relative to feeding station grass biomass levels remained similar $\left(F_{4,198}=0.64, P=0.64\right)$. Overall, the mean intake rate was similar among grassland types: frequently burned $(19.1 \pm 2.5 \mathrm{~g} / \mathrm{min})$, infrequently burned $(19.0 \pm 3.2 \mathrm{~g} / \mathrm{min})$, and not-burned watersheds $(21.7 \pm 2.6 \mathrm{~g} / \mathrm{min}$; Fig. $4 \mathrm{C})$. Results of
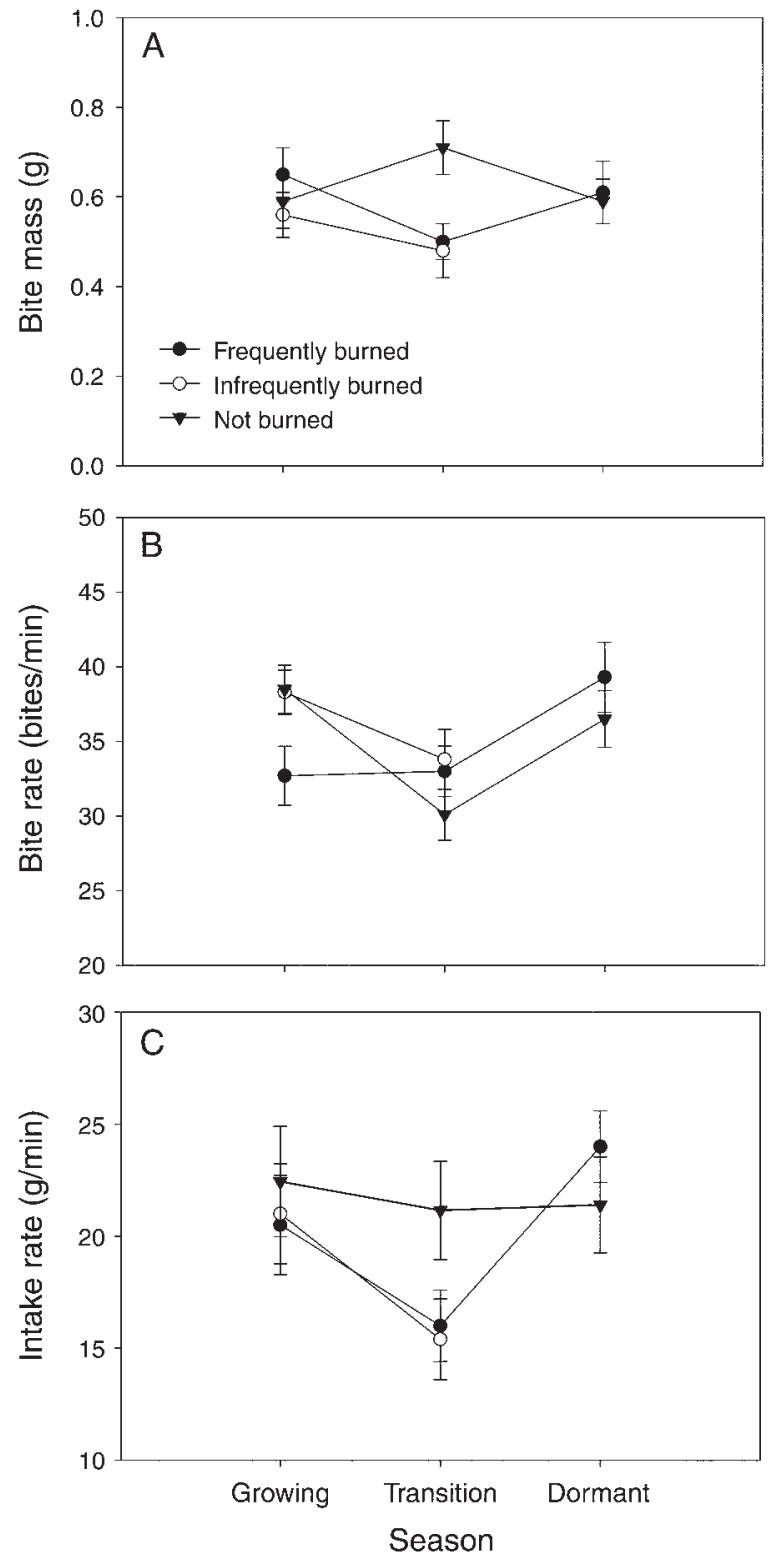

FIG. 4. Seasonal changes (and $95 \% \mathrm{CI}$ ) in (A) mean bite mass; (B) mean bite rate; (C) mean intake rate across burn treatments by plains bison pooled across 2012-2013.

feeding measures across seasons by burn treatment with increasing live grass mass, feeding measures across seasons irrespective of burn treatments, feeding station nutrient intake rate across seasons irrespective of burn treatments, and patterns in grazing activity are summarized in Appendix B.

\section{DisCUSSION}

Spatial heterogeneity in forage quality and quantity in tallgrass prairie is driven by fire-grazer interactions, leading to a shifting mosaic of not only vegetation characteristics, but also the distribution and foraging behavior of grazers (Fuhlendorf et al. 2009, Allred et al. 
2011a). A new appreciation for the complementary nature of the FMH and the TMH emerges from our study, and sets the stage for mediating food-processing rates at feeding stations and grazer aggregation responses to these patches at watershed levels. While the TMH was previously applied with the goal of understanding how primary productivity responds to disturbance when controlled by contrasting limiting factors at equilibrium states, we extend the importance of this mechanism to the next trophic level. Moreover, the impact of grazing on vegetation quantity and quality can mediate forage intake by grazers through the FMH to maintain seasonally attractive and profitable patches. Recent burning of infrequently burned areas leads to especially attractive patches for grazers (from the TMH), that then remain so because of subsequent grazing in accordance with the FMH.

\section{Fine-scale foraging behavior and fire frequency}

Fine-scale feeding behaviors ultimately contribute to coarse-scale foraging decisions and landscape distribution by large herbivores (Senft et al. 1987). We assessed how fine-scale feeding behaviors by bison in recently burned watersheds responded to fire frequency in tallgrass prairie. Observational and experimental data indicate that variation in fire frequency plays a significant role for understanding seasonal changes in large-herbivore foraging behavior. Moreover, the time since last burn in watersheds with different burn histories is a critical link between fire and grazing and is an important driver behind variation in feeding measures at this fine scale. Our results indicate that bison feeding responses to forage availability and quality at the feeding station are influenced by fireinduced transient maxima dynamics.

During the early growing season, ungulates restore fat and body mass lost during the winter dormant season, a period during which grazers often compensate behaviorally for nutrient-poor foods by ingesting more food (Illius 2002). A greater rate of increase in bite mass and instantaneous intake rate during the growing season than in the transitional season in infrequently burned watersheds indicates that bison adjusted their consumption rate to maximize their use of forage when it was in a state of greatest nutritional value in this fire treatment. Furthermore, bite rate declined more rapidly during the transitional season in the infrequently burned treatment, indicating that handling time increased with plant maturity consistent with FMH predictions. Ingestion constraints may be less limiting with increasing forage biomass when food has high protein content and palatability, thus allowing large grazers to attain sufficient protein for maintenance requirements (Van Soest 1994, McArt et al. 2009). This observation may explain why nutritional enhancement of grasslands through periodic burning does not reduce stocking rate, deferment, or rest in cattle when compared to annually burned grassland (Limb et al. 2011). As maximizers of short-term gain (Bergman et al. 2001, Fortin et al. 2002), bison may be foraging in infrequently burned areas in spring to gain mass most rapidly because summer dietary $\mathrm{N}$ intake greatly affects body mass (Hjeljord and Histol 1999, McArt et al. 2009), or to allocate more time for raising young, regulating thermal balance, or maintaining social status. If true, the time saved by selecting a diet that maximizes short-term intake should also improve fitness (Fortin et al. 2002).

\section{Response to transient maxima resource availability}

The TMH complements the FMH by providing a useful mechanistic framework for understanding grazing herbivores in nutritionally heterogeneous, mesic grasslands; the pulse in forage quantity and quality made available by periodic burning corresponds to patterns of large herbivore use during the early growing season (Archibald and Bond 2004). Periodic fire is essential for the development and maintenance of tallgrass prairie ecosystems, and has strong effects on productivity (Briggs and Knapp 1995, Blair 1997) and nutrient cycling rates (Seastedt and Ramundo 1990, Ojima et al. 1994). Throughout the study period, standing crop of grass biomass was generally lower in infrequently burned watersheds that burned in the spring of that year (late March), followed by intermediate levels of grass biomass in frequently burned watersheds also burned in the spring of that year, with the highest grass biomass observed in watersheds not burned the previous spring (Fig. 2A). This observation is consistent with the FMH that posits grasslands are maintained by aggregations of large herbivores in a state of low to intermediate quantity (Fryxell 1991, Hebblewhite et al. 2008). Furthermore, bison in tallgrass prairie are sometimes known to use recent burns even after they are virtually devoid of vegetation (Mitchell et al. 1996, Schuler et al. 2006). Foraging at locations offering low to intermediate levels of vegetation, where foragers trade off food digestibility and availability, corresponds to expectations where herbivores maximize energy and nutrient intake rate (Fryxell 1991, Bergman et al. 2001). Fine-scale foraging behavior by the KPBS bison herd can be viewed as a trade-off between forage quality and quantity where fire attracts aggregations of large herbivores, especially to periodically burned watersheds, and subsequent prevention of forage maturation by grazing in burned watersheds guides the spatiotemporal distribution of grazers as long as regrowth is possible. Although the generality of these results to other grasslands remains to be tested, we anticipate that this interaction between nonequilibrial forage resources and ungulate foraging behavior is a key driver for ungulate distributions in fire-prone systems generally.

\section{Bison nutrient acquisition in the tallgrass prairie}

Ungulates increase forage intake following periods of low food availability to regain body condition in both arctic and alpine systems and to compensate for a 
decline in food quality during the dry season (Van der Wal et al. 2000, Hamel and Côté 2008). In arid systems, equids reduce intake rate during the dormant season when plant greenness is lowest (St-Louis and Côté 2012), although the behavioral mechanism behind reduced intake rate is poorly understood and has not been addressed in temperate systems with an intact firegrazer interaction. In the Serengeti, Thomson's gazelles (Gazella thomsoni thomsoni) compensate for unfavorable temporal variation in resource availability (e.g., due to depletion of quality resources) at small spatial scales (Fryxell et al. 2005). In bison, we found that bite quality during the growing season was positively associated with plant nutrients and bite mass was negatively associated with plant structural properties. Late summer bite quality and bite mass were positively associated with plant digestibility and plant structural properties, respectively. The inverse relationship between bite mass and plant structural properties observed in the growing season differed from feeding station behavior during late summer when both average short-term forage intake and nutrient intake rate were minimal. A reduced nutrient intake rate observed in the dormant season indicates bison were compensating for low foliar nutrient availability by increasing bite mass and intake rate. This pattern was most pronounced during 2013 when forage quality did not increase in late summer with increased precipitation, as an increase in forage quality was observed in late summer of 2012 when precipitation was markedly reduced.

Foliar protein concentration in grasses often increases in years of reduced precipitation (Milchunas et al. 1995, Joern and Mole 2005). Bite mass and intake rate increased during the late summer of 2013 while protein content of available green forage continued to decline. We surmise bison were compensating for low protein availability by consuming more forage, consistent with other studies (Laca et al. 1994), rather than mobilizing fat reserves to meet shortfalls in nutrient needs (Shrader et al. 2006). Our interpretation of this behavioral adjustment is that bison were compensating for lower forage quality in late summer by consuming more food to keep the rumen microbial system primed with adequate protein content for microbes to maximize gains during critical times of the year (Faverdin 1999). This shift in foraging behavior at the end of the growing season may be a mechanism to modulate reduction in mass, which occurs at KPBS in years without late summer rains and without the concomitant flush of protein availability (Craine et al. 2009). Results presented here demonstrate an extension of the TMH to an additional trophic level, consumers, and how it complements the FMH, but we also demonstrate foraging and nutrient acquisition tactics of a large, native grazer at the finest scale of foraging in a landscape with an intact fire-grazer interaction, which, to our knowledge, has not been investigated.

\section{Synthesis}

The interplay between fire-induced nutritional enhancement of forage and temporal variation in feeding behavior suggests that fine-scale foraging is an integral component of understanding the role of fire on bison distribution and foraging activity in this nutritionally heterogenous landscape. The observed increase in bite mass and instantaneous intake rate of individual bison during the growing season in periodically burned grassland indicates that the "pulse" of $\mathrm{N}$ availability and ANPP driven by fire in previously light-limited, unburned grassland modulated ungulate foraging behavior. Thus, the importance of fire in controlling grazer behavior at the feeding station scale was temporally contingent upon fire frequency, the elapsed time since the last burn, and the timing of plant productivity pulses. Whether such behavioral responses occur in grasslands where burning occurs at other times of the year remain unclear.

The dynamics of feeding station use in this study sheds light on how grazing herbivores respond to nutritionally heterogeneous forage resources across seasons and between years of contrasting forage quality and availability. Although resource depletion is known to change the dormant season habitat selection of temperate ungulates due to the trade-off between forage quality and quantity (van Beest et al. 2010), our data clarify how temperate ungulates shift foraging behaviors in response to forage depletion at the feeding station scale.

Our investigation of fine-scale foraging behavior in mesic grasslands when fire results in markedly different nutritional value also provides baseline information for forecasting animal foraging behavior in other fire-prone ecosystems. While grassland fires are known to have pronounced effects on landscape scale distributions of large herbivores (Sensenig et al. 2010, Allred et al. $2011 a, b$ ), we conclude that the fine-scale behavioral mechanism associated with foraging at the feeding station is also responsible for herbivore affinity to recently burned grassland. Our data suggest that fireinduced heterogeneity in vegetation quality may be an important landscape scale process that helps promote nutrient attainment in a historically important native grazer and illustrates the utility of linking optimal foraging theory with insights from consumer resource and fire ecology.

\section{ACKNOWLEDGMENTS}

We thank H. Tetreault, J. Girvin, K. Girvin, G. Samms, and T. Stringer for assistance during the project. J. Blair, K. Gido, J. Gomez, and E. Welti provided useful discussion and comments on the manuscript. We also thank A. Shrader and an anonymous reviewer for extremely helpful comments on a previous version of the manuscript. We are grateful to $\mathrm{L}$. Murray for statistical advice. The Konza Prairie is owned by the Nature Conservancy and managed by Kansas State University Division of Biology. We are grateful for support from NSF/DEB 1020485 (to A. Joern), the NSF Konza LTER, and the Division of Biology, KSU. We acknowledge fellowship 
support to E. J. Raynor from the KSU NSF GK-12 program (DGE-0841414). This paper is a contribution of the Kansas Agricultural Experiment Station (manuscript number 15-204$\mathrm{J})$.

\section{Literature Cited}

Allred, B. W., S. D. Fuhlendorf, D. M. Engle, and R. D Elmore. 2011a. Ungulate preference for burned patches reveal the strength of fire-grazing interaction. Ecology and Evolution 1:132-144.

Allred, B. W., S. D. Fuhlendorf, and R. G. Hamilton. $2011 b$. The role of herbivores in Great Plains conservation: comparative ecology of bison and cattle. Ecosphere 2:art26. http://dx.doi.org/10.1890/ES10-00152.1

Altmann, J. 1974. Observational study of behavior: sampling methods. Behaviour 49:227-267.

Anderson, T. M., M. E. Ritchie, E. Mayemba, S. Eby, J. B. Grace, and S. J. McNaughton. 2007. Forage nutritive quality in the Serengeti ecosystem: the roles of fire and herbivory. American Naturalist 170:343-357.

Archibald, S., and W. Bond. 2004. Grazer movements: spatial and temporal responses to burning in a tall-grass African savanna. International Journal of Wildland Fire 13:377-385.

Archibald, S., W. J. Bond, W. D. Stock, and D. H. K. Fairbanks. 2005. Shaping the landscape: fire-grazer interactions in an African savanna. Ecological Applications 15:96109.

Augustine, D. J., and J. D. Derner. 2014. Controls over the strength and timing of fire-grazer interactions in a semi-arid grassland. Journal of Applied Ecology 51:242-250.

Bailey, D. W., J. E. Gross, E. A. Laca, L. R. Rittenhouse, M. B. Coughenour, D. M. Swift, and P. L. Sims. 1996. Mechanisms that result in large herbivore grazing distribution patterns. Journal of Range Management 49:386-400.

Bergman, C. M., J. M. Fryxell, C. C. Gates, and D. Fortin. 2001. Ungulate foraging strategies: energy maximizing or time minimizing? Journal of Animal Ecology 70:289-300.

Bischof, R., L. Loe, E. Meisingset, B. Zimmermann, B. Van Moorter, and A. Mysterud. 2012. A migratory ungulate in the pursuit of spring: jumping or surfing the green wave? American Naturalist 180:407-424.

Blair, J. M. 1997. Fire, N availability, and plant response in grasslands: a test of the transient maxima hypothesis. Ecology 78:2359-2368.

Briggs, J. M., and A. K. Knapp. 1995. Interannual variability in primary production in tallgrass prairie: climate, soil moisture, topographic position, and fire as determinants of aboveground biomass. American Journal of Botany 82:1024-1030.

Coppedge, B. R., D. M. Leslie, and J. H. Shaw. 1998. Botanical composition of bison diets on tallgrass prairie in Oklahoma. Journal of Range Management 51:379-382.

Coppedge, B. R., and J. H. Shaw. 1998. Bison grazing patterns on seasonally burned tallgrass prairie. Journal of Range Management 51:258-264.

Craine, J. M., E. G. Towne, A. Joern, and R. G. Hamilton. 2009. Consequences of climate variability for the performance of bison in tallgrass prairie. Global Change Biology 15:772-779.

Dancose, K., D. Fortin, and X. Guo. 2011. Mechanisms of functional connectivity: the case of free-ranging bison in a forest landscape. Ecological Applications 21:1871-1885.

Drescher, M., I. M. A. Heitkönig, P. J. van den Brink, and H. H. T. Prins. 2006. Effects of sward structure on herbivore foraging behavior in a South African savanna: an investigation of the forage maturation hypothesis. Austral Ecology 31: 76-87.

Eby, S. L., T. M. Anderson, E. P. Mayemba, and M. E. Ritchie. 2014. The effect of fire on habitat selection of mammalian herbivores: the role of body size and vegetation characteristics. Journal of Animal Ecology 83:1196-1205.
Faverdin, P. 1999. The effect of nutrients on feed intake in ruminants. Proceedings of the Nutrition Society 58:523-531.

Fortin, D., J. M. Fryxell, and R. Pilote. 2002. The temporal scale of foraging decisions in bison. Ecology 83:970-982.

Fryxell, J. M. 1991. Forage quality and aggregation by large herbivores. American Naturalist 138:478-498.

Fryxell, J. M., J. F. Wilmshurst, A. R. E. Sinclair, D. T. Haydon, R. D. Holt, and P. A. Abrams. 2005. Landscape scale, heterogeneity, and the viability of Serengeti grazers. Ecology Letters 8:328-335.

Fuhlendorf, S. D., and D. M. Engle. 2001. Restoring heterogeneity on rangelands: ecosystem management based on evolutionary grazing patterns. BioScience 51:625-632.

Fuhlendorf, S. D., and D. M. Engle. 2004. Application of the fire-grazing interaction to restore a shifting mosaic on tallgrass prairie. Journal of Applied Ecology 41:604-614.

Fuhlendorf, S. D., D. M. Engle, J. Kerby, and R. Hamilton. 2009. Pyric herbivory: rewilding landscapes through recoupling of fire and grazing. Conservation Biology 23:588-598.

Hamel, S., and S. D. Côté. 2008. Trade-offs in activity budget in an alpine ungulate: contrasting lactating and non-lactating females. Animal Behavior 75:217-227.

Hebblewhite, M., E. H. Merrill, and G. McDermid. 2008. A multi-scale test of the forage maturation hypothesis for a partially migratory montane elk population. Ecological Monographs 78:141-166.

Hjeljord, O., and T. Histol. 1999. Range-body mass interactions of a northern ungulate - a test of hypothesis. Oecologia 119:326-339.

Hobbs, N. T., and D. W. Swift. 1988. Grazing in herds: When are nutritional benefits realized? American Naturalist 131: $760-764$.

Illius, A. W., P. Duncan, C. Richard, and P. Mesochina. 2002. Mechanisms of functional response and resource exploitation in browsing roe deer. Journal of Animal Ecology 71:723-734.

Janis, C., and D. Ehrhardt. 1988. Correlation of relative muzzle width and relative incisor width with dietary preference in ungulates. Zoology Journal of the Linnaean Society 92:267284.

Joern, A., and S. Mole. 2005. The plant stress hypothesis and variable responses by blue grama grass (Bouteloua gracilis) to water, mineral nitrogen and insect herbivory. Journal of Chemical Ecology 31:2069-2090.

Kerby, J. D., S. D. Fuhlendorf, and D. M. Engle. 2007. Landscape heterogeneity and fire behavior: scale-dependent feedback between fire and grazing processes. Landscape Ecology 22:507-516.

Knapp, A. K., J. M. Blair, J. M. Briggs, S. L. Collins, D. C. Hartnett, L. C. Johnson, and E. G. Towne. 1999. The keystone role of bison in North American tallgrass prairie. BioScience 49:39-50.

Knapp, A. K., et al. 2012. A test of two mechanisms proposed to optimize grassland aboveground primary productivity in response to grazing. Journal of Plant Ecology 5:357-365.

Laca, E. A., E. D. Ungar, and M. W. Demment. 1994. Mechanisms of handling time and intake rate of a large mammalian grazer. Applied Animal Behaviour Science 39:319.

Limb, R. F., S. D. Fuhlendorf, D. M. Engle, J. R. Weir, R. D. Elmore, and T. G. Bidwell. 2011. Pyric-herbivory and cattle performance in grassland ecosystems. Rangeland Ecology and Management 64:659-663.

McArt, S. H., D. E. Spalinger, W. B. Collins, E. R. Schoen, T. Stevenson, and M. Bucho. 2009. Summer dietary nitrogen availability as a potential bottom-up constraint on moose in south-central Alaska. Ecology 90:1400-1411.

McNaughton, S. J. 1979. Grazing as an optimization process: grass-ungulate relationships in the Serengeti. American Naturalist 113:691-703.

McNaughton, S. J. 1986. Grazing lawns: on domesticated and wild grazers. American Naturalist 128:937-939. 
Milchunas, D. G., O. E. Sala, and W. K. Lauenroth. 1988. A generalized model of the effects of grazing by large herbivores on grassland community structure. American Naturalist 132: 87-106.

Milchunas, D. G., A. S. Varnamkhasti, W. K. Lauenroth, and H. Goetz. 1995. Forage quality in relation to long-term grazing history, current-year defoliation, and water resource. Oecologia 101:366-374.

Miller, W. J., C. M. Clifton, O. L. Brooks, and E. R. Reaty. 1965. Influence of harvesting age and season on digestibility and chemical composition of pelleted coastal bermudagrass. Journal of Dairy Science 48:209-212.

Mitchell, R. B., R. E. Masters, S. S. Waller, K. J. Moore, and L. J. Young. 1996. Tallgrass prairie vegetation response to spring burning dates, fertilizer, and atrazine. Journal of Range Management 49:131-136.

Morris, D. W. 1987. Ecological scale and habitat use. Ecology 68:362-369

Ojima, D., D. S. Schimmel, W. J. Parton, and C. E. Owensby. 1994. Long- and short-term effects of fire on nitrogen cycling in tallgrass prairie. Biogeochemistry 24:67-84.

Owen-Smith, N. 2002. Adaptive herbivore ecology. Cambridge University Press, New York, New York, USA.

Pfeiffer, K. E., and D. C. Hartnett. 1995. Bison selectivity and grazing responses of little bluestem in tallgrass prairie. Journal of Range Management 48:26-31.

Prins, H. H. T., and F. van Langevelde, editors. 2008. Resource ecology: spatial and temporal dynamics of foraging. Springer, Dordrecht, The Netherlands.

Ruyle, G. B., O. Hasson, and R. W. Rice. 1987. The influence of residual stems on biting rates of cattle grazing Eragrostis lehmanniana Nees. Applied Animal Behavior Science 19:1117.

SAS Institute. 2010. SAS System 9.2. SAS Institute, Cary, North Carolina, USA.

Schaefer. J. A., and F. Messier. 1995. Winter foraging by muskoxen: a hierarchical approach to patch residence time and cratering behavior. Oecologia 104:39-44.

Schuler, K. L., D. M. Leslie, J. H. Shaw, and E. J. Maichak. 2006. Temporal-spatial distribution of American bison (Bison bison) in a tallgrass prairie fire mosaic. Journal of Mammalogy 87:539-544.

Seastedt, T. R., and A. K. Knapp. 1993. Consequences of nonequilibrium resource availability across multiple time scales: the transient maxima hypothesis. American Naturalist 141:621-633.

Seastedt, T. R., and R. A. Ramundo. 1990. The influence of fire on below-ground processes of tallgrass prairie. Pages 99-177 in S. L. Collins and L. L. Wallace, editors. Fire in North American grasslands. University of Oklahoma Press, Norman, Oklahoma, USA.

Senft, R. L., M. B. Coughenour, D. W. Bailey, L. R. Rittenhouse, O. E. Sala, and D. M. Swift. 1987. Large herbivores foraging and ecological hierarchies. BioScience 37: 789-799.

Sensenig, R. L., M. W. Demment, and E. A. Laca. 2010. Allometric scaling predicts preferences for burned patches in a guild of East African grazers. Ecology 91:2898-2907.

Shrader, A. M., N. Owen-Smith, and J. O. Ogutu. 2006. How a mega-grazer copes with the dry season: food and nutrient intake rates by white rhinoceroses in the wild. Functional Ecology 20:376-384.

Spalinger, D. E., and N. T. Hobbs. 1992. Mechanisms of foraging in mammalian herbivores: new models of functional response. American Naturalist 140:325-348.

St-Louis, A., and S. D. Côté. 2012. Foraging behavior at multiple temporal scales in a wild alpine equid. Oecologia 169:167-176.

Towne, E. G. 2002. Vascular plants of Konza Prairie Biological Station: an annotated checklist of species in a Kansas tallgrass prairie. Sida 20:269-294.

Van Beest, F. M., A. Mysterud, L. E. Loe, and J. M. Milner. 2010. Forage quantity, quality, and depletion as scaledependent mechanisms driving habitat selection of a large browsing herbivore. Journal of Animal Ecology 79:910-922. Van der Wal, R., N. Madan, S. Van Lieshout, C. Dormann, R. Langvatn, and S. D. Albon. 2000. Trading forage quality for quantity? Plant phenology and patch choice by Svalbard reindeer. Oecologia 123:108-115.

van de Vijver, C. A., P. Poot, and H. H. T. Prins. 1999. Causes of increased nutrient concentrations in post-fire regrowth in an East African savanna. Plant and Soil 214:173-185.

Van Soest, P. J. 1994. Nutritional ecology of the ruminant. Comstock Publications, Ithaca, New York, USA.

Van Soest, P. 1996. Allometry and ecology of feeding behavior and digestive capacity in herbivores: a review. Zoo Biology 15:455.

Verweij, R. J. T., J. Verrelst, P. E. Loth, I. M. A. Heitkonig, and A. M. H. Brunsting. 2006. Grazing lawns contribute to the subsistence of mesoherbivores on dystrophic savannas. Oikos 114:108-116.

Vinton, M. A., D. C. Hartnett, E. J. Finck, and J. M. Briggs. 1993. Interactive effects of fire, bison (Bison bison) grazing and plant community composition in tallgrass prairie. American Midland Naturalist 129:10-18.

Waite, R. 1963. Botanical and chemical changes in maturing grass and their effect on its digestibility. Agricultural Progress 38:50-56.

Wilmhurst, J. F., J. M. Fryxell, and P. E. Colucci. 1999. What constrains daily intake in Thomson's gazelle? Ecology 80: $2338-2347$

Wittmer, H. U., B. N. McLellan, and F. W. Hovey. 2006. Factors influencing variation in site fidelity of woodland caribou (Rangifer tarandus caribou) in southeastern British Columbia. Canadian Journal of Zoology 84:537-545.

\section{Supplemental Material}

\section{Ecological Archives}

Appendices A ands B are available online: http://dx.doi.org/10.1890/14-2027.1.sm 